\title{
Micromorphological structure of seeds in some taxa of Vicia L. (Fabaceae) occurring in Azerbaijan
}

\author{
Kamala V. Asadova ${ }^{1}$ \\ Aydin M. Asgarov \\ Genetic Resources Institute of ANAS, Azadlig Ave. 155, Baku \\ AZ1106, Azerbaijan
}

Abstract: For the first time, micromorphology of seed samples and structure of seed surface of the following 17 species and subspecies of the wild vetch (Vicia L.) occurring in the flora of Azerbaijan were studied: $V$. bithynica (L.) L., $V$. sativa subsp. cordata Wulf ex Hoppe, V. elegans Guss., V. hirsuta (L.) S. F. Gray, V. hybrida L., $V$. lutea L., $V$. monantha Retz. ( $V$. cinerea M. Bieb.), $V$. narbonensis L. ( $V$. johannis Tamamsch.), $V$. pannonica Crantz, $V$. peregrina L., $V$. sativa L. subsp. nigra (L.) Ehrh. (V. angustifolia Reichard), V. sativa L. subsp. sativa, V. tetrasperma (L.) Schreb., V. tenuifolia Roth subsp. variabilis (Freyn et Sint. ex Freyn) Dinsm., $V$. villosa Roth subsp. varia (Host) Corb. (V. dasycarpa auct.), $V$. villosa Roth subsp. villosa, and $V$. loiseleurii (M. Bieb.) H. Lindb. (V. meyeri Boiss.). Seed samples were collected in 2015-2017 on 11 routes from different region of Azerbaijan (Zaqatala, Ordubad, Khizi, Shamakhi, Masalli, Qabala, Lerik, and Tovuz). Collected taxa belong to two subgenera (subg. Vicia, subg. Vicilla) and 8 sections (Vicia, Hypechusa, Peregrinae, Faba, Narbonensis, Cracca, Lenticula, and Ervum). In the samples, the surface structures, shape, density or waxy layer of papillae (buds with suction surface) were studied by scanning electron microscopy (SEM). Morphological characters, including general shape, color and size of seeds, were studied under a stereomicroscope. The main form of the seed's surface of the vetch patterns was papilla. However, the size of the ribs in the papillas and the density of papillas were different in different taxa. Four morphological characters of seed (the relative size and shape of the hilum, relative location of the micropile (seed entrance) relative to the hilum and the position of the hilum on the surface of the seed) have been stable. It has been established that the microscopic examination of the seed coat has important taxonomic significance and can be used to clarify the status of subgenera and sections. However, other characteristics of seeds (shape, color, seed size, etc.) can be

Accepted for publication: 10 December 2018

E-mail1: esedzadeo@gmail.com also used in identification of the taxa.

Key Words: Vicia, seed micromorphology, SEM, taxa, section, species

\section{INTRODUCTION}

Vetch (Vicia L.) is one of the most widespread genera of the family Fabaceae Lindl. As with other leguminous plants, taxa of Vicia are also selected for their nitrogenfixing properties. In the roots of the plant, there are nitrogen-fixing bacteria that adopt the atmospheric free nitrogen and convert it into a mineral form that plants can use. During the vegetation period, vetches release these mineral substances into the soil through the roots that enriches the microflora of the soil and fertilize it. Due to this, the productivity of plants grown on the soil after the vegetation period and the quality of crop products rises [Hümbətov, Hüseynov, 2013]. Representatives of the genus Vicia L. are considered to be good predecessors. This genus contains 150-210 species occurring in Europe, Asia, North America, temperate regions of South America, and partly in tropical Africa [Hanelt, Mettin, 1989; Kupicha, 1976; Perrino et al., 1984]. It has been established that in the flora of Azerbaijan the genus Vicia is represented by 2 subgenera, 11 sections, 39 species, 5 subspecies and 8 varieties ranging in their distribution from the sea level to mid-mountain zones [Asadova, Asgarov, 2018; Osgərov, 2011; Osgərov, 2016].

The monographic study of the genus was carried out by F. K. Kupicha [Kupicha, 1973, Kupicha, 1975; Kupicha, 1976]. Using the classic methods, Kupicha, based on selected morphological signs, subdivided Vicia into two subgenera: Vicia and Vicilla (Cracca). These subgenera differ in the relative length of the inflorescence and the presence or absence of nectar spots on the stipule. In their taxonomic studies of the genus Vicia, many scientists used the seed morphology [Büyükkartal, 2013; Gunn, 1970; Jaaska, Leht, 2007; Leht, 2005; Leht, 2009; Leokene, 1966; Perrino et al., 1984; Willis, 1973; Zertova, 1962], including micromorphology of the seed texture [Chernoff et al., 1992; Gunn, 1969; Gunn, 1970; Güneş, Ali, 2011; Hosseinzadeh et al., 2008; Kikbride et al., 2003; Lersten, 1979; Lersten, Gunn, 1981; Mettin, Hanelt, 1964; Utkin, 1965]. 
The purpose of the seed is the size, general appearance, size of the hilum, and so on based on some morphological features. In the classification of species, in the phylogenetic relationships of intraspecific taxa the signs of the seed can be used as an important indication. In the first description of some vetches, as well as in "Flora" [Boissier, 1872; Grossqeym, 1952; Tamamshian, 1954], in their characteristics do not show signs of seed. In this article, the morphology and in particular micromorphology of vetch seeds were investigated and the structure of the seeds of these species was studied using SEM and were detected constant morphological characters (shape, size of the seeds; shape, location of the hilum in the seeds, and the sculpture of the seed surface).

\section{MATERIAL AND METHODS}

Specimen collection. The material for the study consisted of seeds of species of Vicia ( $V$. sativa subsp. cordata, V. sativa subsp. nigra, $V$. sativa subsp. sativa, $V$. pannonica, $V$. hybrida, V. lutea, V. peregrina, V. bithyni$c a, V$. narbonensis, $V$. tenuifolia subsp. variabilis, V. villosa, $V$. varia, $V$. monantha, $V$. elegans, $V$. hirsuta, $V$. loiseleurii, $V$. tetrasperma), which we collected during the expeditions to different regions of Azerbaijan (Zaqatala, Ordubad, Khizi, Shamakhi, Masalli, Qabala, Lerik, and Tovuz) under the guidance of A. Asgarov in 2015-2017. We indicated information on the collection area, biotope, geographic coordinates and altitude of each seed sample in the special descriptions. Hipsometric altitude and area coordinates were measured with a Garmin eTex 20 model GPS device according to WGS-84 (G873) (World Geodetic System). The most commonly accepted classification is the classification of Kupicha, so we accepted that classification in own work [Kupicha, 1976]. However, it should be noted that new phylogenetic results indicate that the genus Vicia, as traditionally understood, is not monophyletic [Endo, 2010; Fedoronchuk, 2018; Fedoronchuk, Mosyakin, 2018; Schäfer et al., 2012]. We used terminology adopted by some authors cited in our article [Chernoff et al., 1992; Fedoronchuk, Mosyakin, 2018; Güneş, Ali, 2011; Hosseinzadeh et al., 2008; Jalilian, 2011; Jalilian et al., 2010; Jalilian, Rahiminejad, 2012; Leht, 2009; Lersten, 1979; Maxted, 1993; Tamamshian, 1954; Voronchikh, 1988].

Microscopic studies. SEM analysis of plant seeds has been done on a microscope JEOL JSM 6610 LV. Modern plant seeds (both living and herbarium specimens) usually do not require special treatment for SEM. They are sufficiently dried in air. Seeds were transferred with a special tool to previously prepared special tables covered with double adhesive carbon tape. To minimize the static effect, the samples were sprayed with golden powder for 1-2 minutes through the JEOL JFC-1100E (JEOL Ltd., Tokyo, Japan) ion sputter coater. Seeds can also be examined in the low vacuum mode without metal spraying. After that the table was placed in a microscope for SEM analysis. A general view of the seed surface and the observed features of the sculpture at high and low magnifications were photographed with a JEOL JSM6610 LV electron microscope (JEOL Ltd., USA). This microscope photographed nearly 1500 times or more in order to explore the microstructure of the seed's surface. Sometimes it was found useful to tilt the table; for example, to consider a weakly expressed sculpture. Also, on the cracked objects we can see the internal structure of the shells, which is also more convenient to do by tilting the table. The obtained data were stored on removable storage media. General shape, color and size of seeds were studied under a stereomicroscope Leica EZ4D (USA).

\section{RESULTS AND DISCUSSION}

During expeditions were collected seeds of 17 taxa of Vicia belonging to 2 subgenera and 8 sections (according to the system of Kupicha): $V$. sativa subsp. cordata, $V$. sativa subsp. nigra, $V$. sativa subsp. sativa) (sect. Vicia); V. hybrida, V. lutea, V. pannonica (sect. Hypechusa); V. peregrina (sect Peregrinae); V. bithynica (sect. Faba); V. narbonensis (sect. Narbonensis); V. tenuifolia subsp. variabilis, $V$. villosa, $V$. varia, $V$. monantha, V. elegans (sect. Cracca); $V$. hirsuta, V. loiseleurii (sect. Lenticula)), and V. tetrasperma (sect. Ervum). The distribution of Vicia taxa collected from different research areas (by subgenera and sections) and descriptions of the collected seed samples are provided below:

\section{Subgenus: Vicia}

Sect.: Vicia-Annual or perennial, often climbing. Stipules without a dark nectariferous spot. Leaflets usually many-paired, small or medium-sized. Peduncle shorter than the usually 1 to few flowers, or absent. Flowers yellow to purple-violet. Calyx teeth subequal to unequal. Style compressed, usually with a tuft of hairs on the lower side towards the apex. Legumes with coriaceous valves, not torulose, less than $13 \mathrm{~mm}$ broad, glabrous or hairy; seeds few to many.

Seed pattern: V. sativa L. subsp. cordata Wulf ex Hoppe Locality code AZE17St2; Collection area Lerik region, 
Piran village; Biotope Rock crumple; GPS coord.: N 38 $73^{1} 369$; E 48 $66^{1} 735$; Altitude $207 \mathrm{~m}$

Seed pattern: V. sativa L. subsp. nigra (L.) Ehrh. Locality code AZE17M6; Collection area Masalli region, Gizilagaj village; Biotope meadow GPS coord.: N $39^{\circ} 03^{\prime} 0$; E 4849'4; Altitude $23 \mathrm{~m}$

Seed pattern: $V$. sativa L. subsp. sativa Locality code AZE17K20; Collection area Shamakhi region, Mirzandiya village; Biotope meadow; GPS coord.: N 40³4'737; E 4843'648; Altitude $584 \mathrm{~m}$

Sect.: Hypechusa (Alef.) Aschers. \& Graebner - annual plant, stems with partial replacement of cortical vascular bundles at the nodes. Leaves tendrillous; leaflets many-paired. Inflorescence many to 1-flowered. Flowers pedunculate or sessile in leaf-axils, yellowish or very rarely purplish, calyx irregular; legume rhomboidal (sutures not parallel). Seeds with medium to short hilum; micropile on opposite side of the seed from the hilum; testa smooth.

Seed pattern: $V$. hybrida L.

Locality code AZE16D6; Collection area Shamakhi district, Shamakhi-Agsu highway; Biotope roadside; GPS coord.: N 40³8'550; E 48²8’450; Altitude $794 \mathrm{~m}$

Seed pattern: V. lutea L.

Locality code AZE17K19; Collection area Shamakhi region, Pirgulu village; Biotope forest; GPS coord.: N 4046’864; E 48³6’168; Altitude $1430 \mathrm{~m}$

Seed pattern: $V$. pannonica Crantz

Locality code AZE17K20; Collection area Shamakhi region, Mirzandiya village; Biotope meadow; GPS coord.: N 40³4'737; E 4843'648; Altitude $584 \mathrm{~m}$

Sect.: Peregrinae Kupicha - annual plant, stems with complete replacement of cortical vascular bundles at the nodes. Leaves tendrillous, multijugate. Inflorescence 1-flowered, not pedunculate but flowers are on fairly long pedicels. Flowers whitish, pale yellow or dark violet. Calyx irregular; legume rhomboidal. Seeds with very short hilum; micropile near the hilum; testa smooth.

Seed pattern: $V$. peregrina $\mathrm{L}$.

Locality code AZE17K20; Collection area Shamakhi region, Mirzandiya village; Biotope meadow; GPS coord.: N 40³4'737; E 48²43'648; Altitude 584 m

Sect.: Faba (Miller) Ledeb. - Annuals, seldom climb- ing. Leaflets 1-3- paired, larger than Sect. Vicia. Peduncle shorter or sometimes longer than the large (16-30 $\mathrm{mm})$ flowers. Flowers purplish or bicoloured. Calyx teeth subequal to unequal. Style compressed, with a tuft of hairs on the lower side towards the apex. Legume (with coriaceous hairy valves) and seeds usually larger than in other Sections.

Seed pattern: $V$. bithynica (L.) L.

Locality code AZE17M6; Collection area Masalli region, Gizilagaj village; Biotope meadow GPS coord.: N 3903'0; E 4849'4; Altitude 23 m

Sect.: Narbonensis (Radzhi) Maxted - Annual. Erect; stem stout. Stipules semi sagittate; Leaf 7-126 mm; apex tendrilous; 2-12 leaflets per leaf; Peduncle with 1-6 flowers. Calyx mouth oblique; Flowers 14-36 mm; all petals approximately equal length; standard cream, blue or purple. Legume; rectangular or rhomboid; valves pubescent; hairs tuberculate; septa absent or present; $2-9$ seeds per legume. Seeds round; hilum less than quarter of seed circumference; micropyle positioned near hilum; testa surface smooth.

Seed pattern: $V$. narbonensis L. ( $V$. johannis Tamamsch.)

Locality code AZE17Z9; Collection area Qabala region, Amirvan village; Biotope bank of river; GPS coord.: N 400 81'906; E 47088'421; Altitude 535 m

Subgenus: Vicilla (Schur) Rouy

Sect.: Cracca S. F. Gray - Annual to perennial, often climbing. Stipules without a dark nectariferous spot. Leaflets few- many- paired, small to large. Peduncle usually much longer than the 1- many flowers. Flowers usually blue- lilac to purplish- red, rarely yellow. Calyx usually irregular and gibbous. Style compressed, equally pubescent all round near the apex. Legumes with coriaceous, glabrous or hairy valves, not torulose; seeds few to many.

Seed pattern: $V$. tenuifolia Roth subsp. variabilis (Freyn $\&$ Sint. ex Freyn) Dinsm.

Locality code AZE17K19; Collection area Shamakhi region, Pirgulu village; Biotope forest; GPS coord.: N 4046'864; E 48³6'168; Altitude $1430 \mathrm{~m}$.

Seed pattern: $V$. villosa Roth subsp. villosa Locality code AZE17K20; Collection area Shamakhi region, Mirzandiya village; Biotope meadow; GPS coord.: N 40³4'737; E 4843'648; Altitude $584 \mathrm{~m}$ 
Seed pattern: $V$. villosa Roth subsp. varia (Host) Corb. (V. dasycarpa auct.)

Locality code AZE15Z2; Collection area Zaqatala region, Yukhari Tala village, Parzivan area; Biotope road-

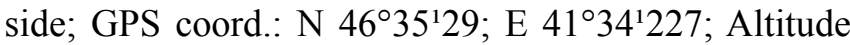
$358 \mathrm{~m}$

Seed pattern: $V$. monantha Retz. (V. cinerea M. Bieb.) Locality code AZE16D6; Collection area Shamakhi district, Shamakhi-Agsu highway; Biotope roadside; GPS coord.: N 40³8'550; E 48²8'450; Altitude $794 \mathrm{~m}$

Seed pattern: V. elegans Guss.

Locality code AZE16E4; Collection area Ordubad region, Tivi village; Biotope foothills; GPS coord.: N

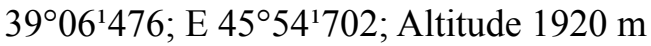

Sect.: Lenticula Aschers. \& Graebn. (=Genus Ervilia Link, sect. Ervilia (Link.) W.D.J.Koch)- Annual, apex tendrilous; leaflets are narrow and linear. The flowers are small, in long flower pedicels; single or multiple. Legume is rhombic; with 2-3 seeds.

Seed pattern: V. hirsuta (L.) S. F. Gray (E. hirsuta (L.) Opiz)

Locality code AZE17TM6; Collection area Tovuz region, Asrik village; Biotope grassland; GPS coord.:

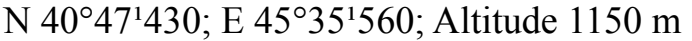

Seed pattern: V. loiseleurii Boiss. (V. meyeri Boiss.) (=E. loiseleurii (M.Bieb.) H.Schaef.)

Locality code AZE16E1; Collection area Ordubad region, Paragha village; Biotope roadside; GPS coord.: N 390 5' 10; E 45055'13; Altitude 1644 m

Sect.: Ervum (L.) S. F. Gray (=Genus Ervum L., sect. Ervum (L.) Taub.,) - Slender annuals, with habit and inflorescence similar to Sect. Cracca, but peduncle 1-6flowered. Flowers smaller (2-14 mm), calyx not gibbous. Style shorter (less than $3 \mathrm{~mm}$ ) and terete, shortly pubescent all round or rarely glabrous. Legumes oblong- rhomboid or linear, frequently torulose, with coriaceous valves; seeds few.

Seed pattern: $V$. tetrasperma (L.) Schreb. (=E. tetraspermum L.)

Locality code AZE16E5 ; Collection area Khizi region, Vardah village, the road to the plateau; Biotope roadside; GPS coord.: N 400 53' 402; E 48056' 959; Altitude $991 \mathrm{~m}$.

Micromorphological structure characteristics of seeds have been analyzed and important diagnostic ele-

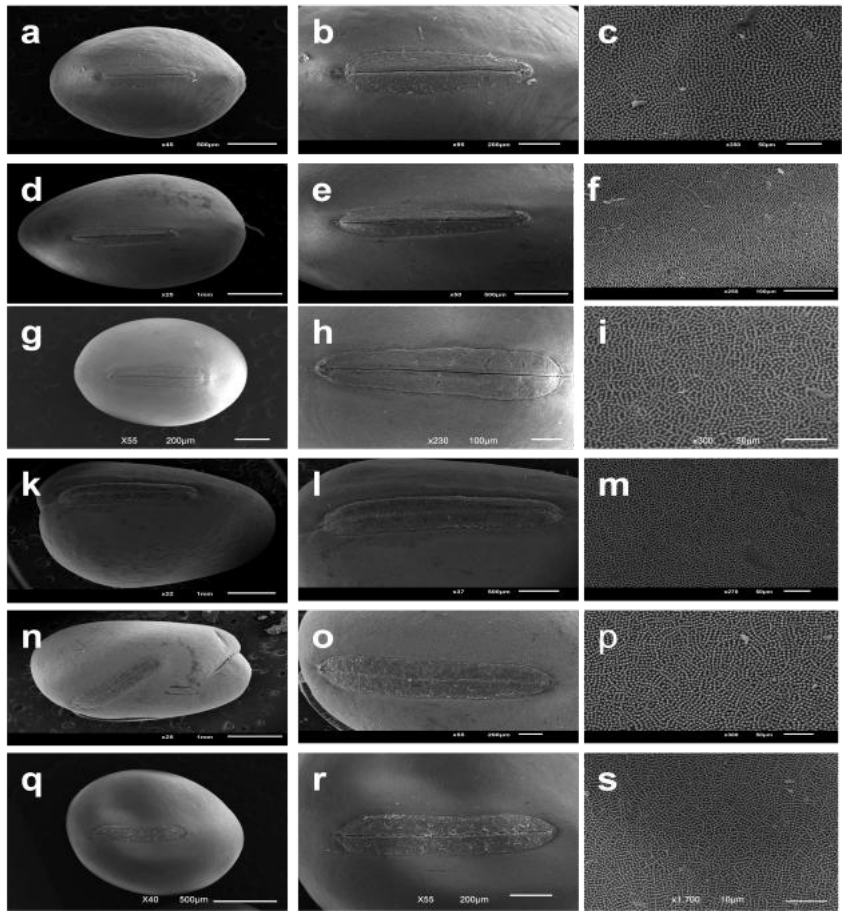

Figure 1. General shape, hilum shape and seed sculpture some of examined taxa: a-c. $V$. sativa subsp. cordata, d-f. V. sativa subsp. sativa, g-i. V. sativa subsp. nigra, k-m. V. hybrida, n-p. V. lutea, q-s. V. pannonica

Scale bars: a-c. 500, 200, $50 \mu \mathrm{m}$; d-f. $1 \mathrm{~mm}, 500,100$ $\mu \mathrm{m}, \mathrm{g}-\mathrm{i} .200,100,50 \mu \mathrm{m}$; k-m. $1 \mathrm{~mm}, 500,50 \mu \mathrm{m}$; n-p. $1 \mathrm{~mm}, 200,50 \mu \mathrm{m}$; q-s. 500, 200, $10 \mu \mathrm{m}$.

ments have been identified that may be useful for systematics of controversial taxa. In this work were studied morphology and in particular micromorphology of seeds in order to investigate the relationships between intraspecific groups of the genus Vicia. Morphological characters of seed samples from 17 vetch taxa and the microsculpture of the seed coat were analyzed using SEM. It has been demonstrated that the seed characters of important taxonomic significance are: the size and shape of the seed, the size and shape of the hilum, and the microscopic appearance of the seed coat.

The majority of seed samples are spherical and oblong. The largest seeds are found in $V$. narbonensis, and the smallest ones in $V$. tetrasperma. Seeds are stained and striped. Hilum can be different of different patterns: long, loose or oval.

In all seed samples, the seed coat is papillate. Papillas are large and small. Density, size and shape of papillas differ depending on the type of the papilla. The density of the papillae is estimated to be moderate to high.

In this study, some characteristics of the seeds were used for the taxonomic delimitation and the identifica- 
tion of them was held according to these characteristics (Table 1). Oblong-ovate hilum was observed in $V$. sativa subsp. cordata, $V$. sativa subsp. nigra, $V$. sativa subsp. sativa, which belong to section Vicia. Broadovate hilum was observed in $V$. bithynica (belonging to sect. Faba), V. narbonensis (sect. Narbonensis), and $V$. loiseleurii (sect. Lenticula). Oblong-elliptic hilum
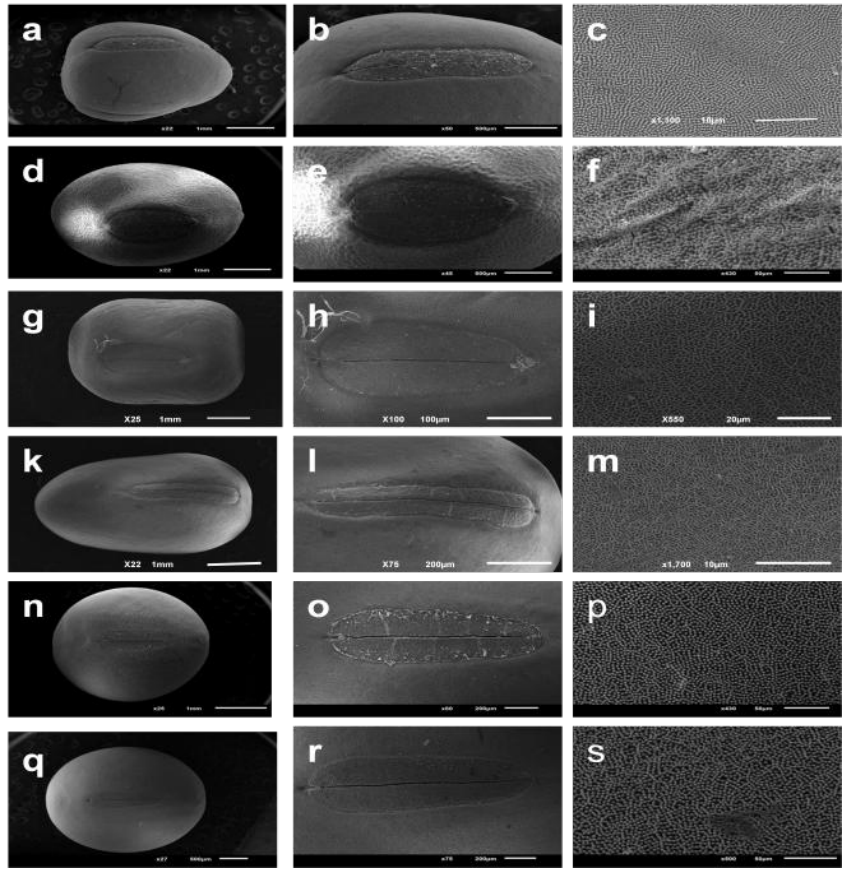

Figure 2. General shape, hilum shape and seed sculpture some of examined taxa: a-c. $V$. peregrina, d-f. $V$. bithynica, g-i. $V$. narbonensis, k-m. V. tenuifolia subsp. variabilis, n-p. $V$. villosa, q-s. $V$. varia.

Scale bars: a-c. $1 \mathrm{~mm}, 200,50 \mu \mathrm{m}$; d-f. $1 \mathrm{~mm}, 500,100$ $\mu \mathrm{m}$; g-i. 200, 100, $50 \mu \mathrm{m}$; k-m. 1mm, 500, $50 \mu \mathrm{m}$; n-p. $1 \mathrm{~mm}, 200,50 \mu \mathrm{m}$; q-s. 500, 200, $10 \mu \mathrm{m}$.

is peculiar to $V$. hirsuta (sect. Lenticula), $V$. tenuifolia subsp. variabilis, $V$. villosa subsp. villosa, $V$. monantha, and $V$. elegans (sect. Cracca). Elliptic hilum was observed in $V$. pannonica, $V$. hybrida, $V$. lutea (sect. Hypechusa), and $V$. peregrina (sect. Peregrinae), but ovate hilum was found in V. tetrasperma (sect. Ervum) and $V$. villosa subsp. varia (sect. Cracca). The papillae with medium density were observed in $V$. narbonensis and V. tenuifolia subsp. variabilis (Fig. 2. g-i, k-m). Dense papilla were observed in $V$. sativa subsp. cordata, $V$. sativa subsp. sativa, V. sativa subsp. nigra (Fig. 1. a-c, d-f, g-i), V. hybrida, V. lutea, V. pannonica (Fig. 1. k-m, n-p, q-s), V. peregrina (Fig. 2. a-c), V. bithynica (Fig. 2. d-f), $V$. loiseleurii (Fig. 3. k-m), V. tetrasperma (Fig. 3. n-p), V. villosa subsp. villosa (Fig. 2. n-p), V. monantha,
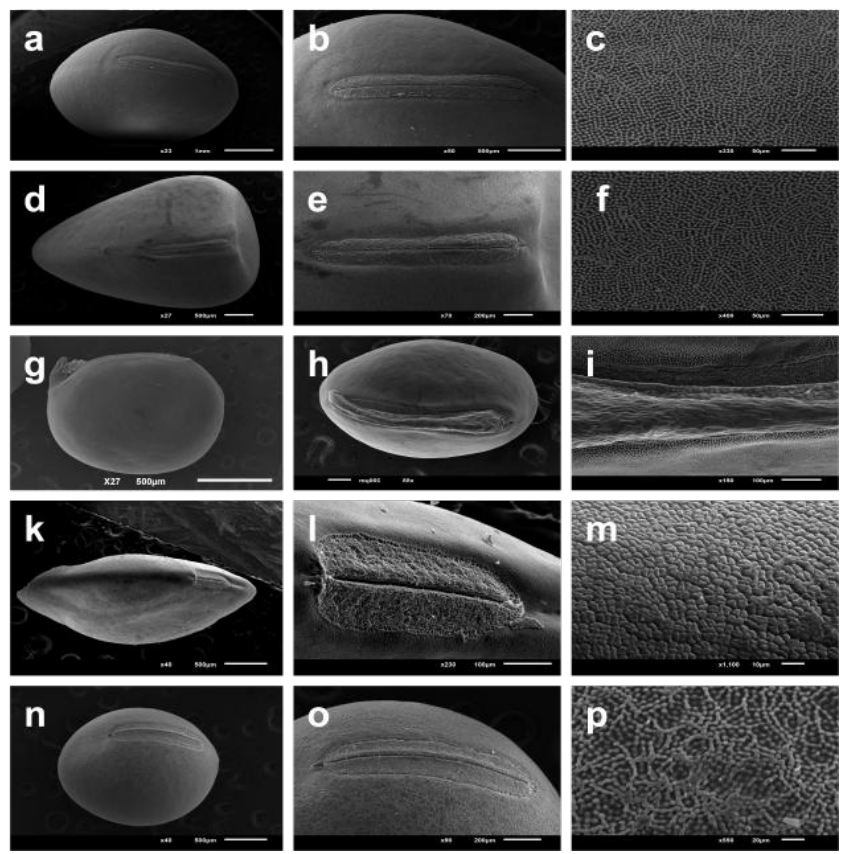

Figure 3. General shape, hilum shape and seed sculpture some of examined taxa: a-c. $V$. monantha, d-f. V. elegans, g-i. V. hirsuta, k-m. V. loiseleurii, n-p. V. tetrasperma

Scale bars: a-c. $1 \mathrm{~mm}, 500,50 \mu \mathrm{m}$; d-f. 500, 200, 50 $\mu \mathrm{m}$; g-i. 200, 100, $10 \mu \mathrm{m}$; k-m. 500, 100, $10 \mu \mathrm{m}$; n-p. $500,200,20 \mu \mathrm{m}$.

and $V$. elegans (Fig. 3. a-c, d-f). Low density papillas are in $V$. hirsuta (Fig. 3. g-i). The result showed that 8 taxa had conical, multirib papillas with waxy specks: $V$. sativa subsp. cordata, $V$. sativa subsp. nigra, $V$. sativa subsp. sativa, V. lutea, V. bithynica, V. narbonensis V. loiseleurii and $V$. villosa subsp. villosa. However, truncate conical papilla were observed in $V$. hirsuta, $V$. loiseleurii and $V$. tetrasperma.

\section{CONCLUSIONS}

The results demonstrated that the microscopic examination of the seed coat has important taxonomic significance and can be used to clarify the status of subgenera and sections. However, other characteristics of seeds (shape, color, seed size, etc.) can be also used in identification of the taxa. Seed characters can be used for taxonomic delimitation and identification of some infrageneric and species-rank taxa, but these characters should be used with caution and preferably in combination with other macro- and micromorphological characters. 


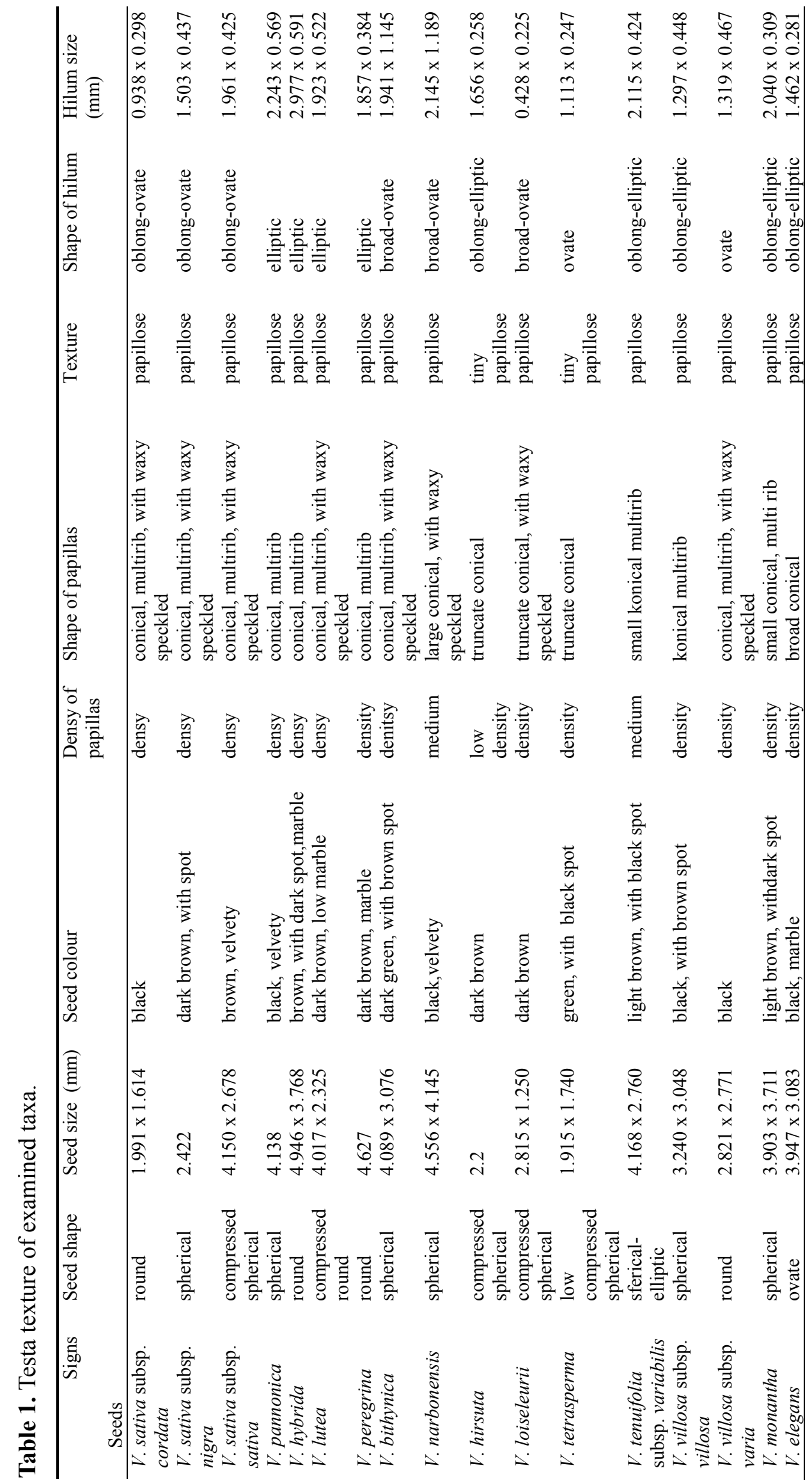




\section{ACKNOWLEDGEMENT}

The authors would like to thank the Institute of Geology and Geophysics, ANAS, Sh. Sh. Bayramova for assisting us to work with the SEM, also G. Sh. Guliyeva and G. F. Allahverdiyeva for help in comparing photos.

\section{REFERENCES}

Asadova K. V., Asgarov A. M. (2018) Distribution and Ecobiological Research of Vetch (Vicia L.) Species in Azerbaijan. IJCRBP, 5(7): 27-36.

Boissier E. (1872) Vicia. In Fl. Orientalis. Genevae \& Basileae, 2: 565-597.

Büyükkartal H. N., Çölgeçen H., Pinar N. M., Erdoğan N. (2013) Seed coat ultrastructure of hard-seeded and soft-seeded varieties of Vicia sativa. Turk. J. Bot., 37: 270-275.

Chernoff M., Plitmann U., Kislev M.E. (1992) Seed characters and testa texture in species of Vicieae: Their Taxonomic Significance. Israel J. Bot., 41: 167-186.

Endo Y., Choi B., Kakinuma D., Kenicer G., Zhu X.-Y., Ohashi H. (2010) Molecular phylogeny of Vicia sect. Amurense (Leguminosae). J. Jap. Bot., 85: 337-349.

Osgərov A.M. (2011) Azərbaycan florasının konspekti. Bak1: Elm, 204 s. (in Azerbaijani)

Osgərov A.M. (2016) Azərbaycanın bitki aləmi. Bakı: TEAS PRESS, 444 s. (in Azerbaijani)

Fedoronchuk M.M. (2018) Konspekt rodini Fabaceae u flori Ukraini. I. Pidrodini Caesalpinioideae, Mimosoideae, Faboideae (tribi Sophoreae, Tephrosieae, Robinieae, Desmodieae, Phaseoleae, Psoraleae, Amorpheae, Aeschynomeneae). Ukr. Bot. J., 75(3): 238-247.

Fedoronchuk M.M., Mosyakin S.L. (2018) Konspekt rodini Fabaceae u flori Ukraini. II. Pidrodini Faboideae (tribi Galegeae, Hedysareae, Loteae, Cicereae) Ukr. Bot. J., 75(4): 305-321.

Gunn C.R. (1969) Genera, types, and lectotypes in the tribe Vicieae (Leguminosae). Taxon, 18: 725-733.

Gunn C.R., C.R. (1970) A key and diagrams for the seeds of one hundred species of Vicia (Leguminosae). Proc. Int. Seed Testing Assoc. 35: 773-790.

Güneş F., Ali Ç. (2011) Seed characteristics and testa textures some taxa of genus Lathyrus L. (Fabaceae) from Turkey. Int. J. Agric. Biol., 13(6): 888-894.

Grossqeym A.A. (1952) Vicia L. V kniqe: Flora Kavkaza. M.- L., 5: 380-398. (In Russian)

Hanelt P., Mettin, D. (1989) Biosystematics of the genus Vicia L. (Leguminosae). Annu Rev Ecol Evol Syst, 20: 199-223.
Hosseinzadeh Z., Pakravan M., Tavassoli A. (2008) Micromorphology of seed in some Vicia species from Iran. Rostaniha, 9: 96-107.

Hümbətov H.S., Hüseynov A.R. (2013) Yem otlar1, Bak1: Elm və təhsil, 184 s. (in Azerbaijani)

Jaaska V., Leht M. (2007) Phylogenetic relationships between and within sections Hypechusa, Narbonensis and Peregrinae of genus Vicia (Fabaceae) based on evidence from isozyme and morphology. Versita, 2(1): 137-155.

Jalilian N. (2011) Taxonomic revision and interspecific relationships of the genus Vicia L. in Iran. Ph.D. thesis, University of Isfahan, Isfahan.

Jalilian N., Rahiminejad M.R., Saeidi H., Maassomi A.A., Maroofi H. (2010) Vicia kurdica (Papilionaceae), a new species from Iran. Feddes Repert., 121 (1-2): 81-84.

Jalilian N., Rahiminejad M.R. (2012) Determination of Vicia species based on seed shape in Iran. Seed Sci Technol, 1: 71-76.

Kikbride J.H., Gunn C.R., Weitzman A. (2003) Fruits and seeds of genera in the subfamily Faboideae (Fabaceae). Technical Bulletin, 1890 (2): 894-893.

Kupicha F.K. (1973) Studies in the Vicieae L.: The new genus Anatropostylia. Notes Royal Bot. Garden. (Edinburgh) 32: 247-250.

Kupicha F.K. (1975) Observations on the vascular anatomy of the tribe Vicieae (Leguminosae). Bot. J. Linnean Soc., 70: 231-242.

Kupicha F.K. (1976) The infrageneric structure of Vicia. Notes Royal Bot. Garden (Edinburgh), 34: 287-326.

Leht M. (2005) Cladistic and phenetic analysis of relationships in Vicia subgenus Cracca (Fabaceae) based on morphological data. Taxon, 54(4): 1023-1032.

Leht M. (2009) Phylogenetics of Vicia (Fabaceae) based on morphological data. Feddes Repert., 120: 379-393.

Leokene L.V. (1966) Morphological seed variations of common vetch species. Bull. Appl. Bot. Genet. Pl. Breed, 38(1): 32-49.

Lersten N.R. (1979) A distinctive seed coat pattern in the Vicieae (Papilionaceae: Leguminosae). Proc. Iowa Acad. Sci. 86: 102-104.

Lersten N.R., Gunn C.R. (1981) Seed morphology and testa topography in Cicer (Fabaceae). Syst. Bot. 6: 223-230.

Maxted N. (1993) A phenetic investigation of Vicia L. subgenus Vicia (Leguminosae, Vicieae). Bot. J. Linn. Soc., 111: 155-182.

Mettin D., Hanelt P. (1964) Cytosystematische Untersu- 
chungen in der Artengruppe um Vicia sativa L. Kulturpflanze, 12: 163-225.

Perrino P., Yarwood M., Hanelt P., Polignano G.B. (1984) Variation of seed characters in selected Vicia species. Kulturpflanze, 32: 103-122.

Schäfer H., Hechenleitner P., Santos-Guerra A., Menezes de Sequeira M., Pennington R.T., Kenicer G., Carine M.A. (2012) Systematics, biogeography, and character evolution of the legume tribe Fabeae with special focus on the middle-Atlantic island lineages. BMC Evol. Biol., 12: 1-250.

Tamamshian S.Q. (1954) Vicia L. V kniqe: Flora Azerbaidjana. Baku, 5: 476-511. (In Russian)

Utkin W.W. (1965) Seeds of wild vetches from the Crimea. Sci. Trans. High Schools. Biol. Sci. 2: 101110.

Voronchikh V.V. (1988) Identification of certain species of the genus Vicia L. from their fruit sand seeds. Vestnik Mosk. Univ. Boil. 36: 22-29.

Willis J.C. (1973) A dictionary of the flowering plants and ferns. Cambridge: Cambridge University Press. $1245 \mathrm{pp}$.

Zertova A. (1962) Ein Schlüssel zur Bestimmung der tschechoslowakischen Arten der Gattung Vicia L. Nach den morphologischen Merkmalen der Samen. Acta Horti. Bot. Pragensis 2: 113-118.

\section{Azərbaycanda yayılan bəzi lərgə taksonlarında toxumların mikromorfoloji quruluşu}

Kəmalə V. Әsədova

Aydın M. Osgərov

AMEA Genetik Ehtiyatlar Institutu, 1106, Azadliq prospekti155, Bakl, Azarbaycan

İlk dəfə olaraq, Azərbaycan florasında yayılan 17 yabanı lərgə (Vicia L.) növü və yarımnövünə aid ( $V$. bithynica (L.) L., V. sativa subsp. cordata Wulf, ex Hoppe, $V$. elegans Guss, $V$. hirsuta (L.) S. F Gray, $V$. hybrida L., $V$. lutea L., $V$. monantha Retz ( $V$. cinerea Bieb.), $V$. narbonensis L. (V. johannis Tamamsch.), V. pannonica Crantz, $V$. peregrina L., V. sativa subsp. nigra (L.)Ehrh. (V. angustifolia Reichard), V. sativa subsp. sativa L., $V$. tetrasperma (L.) Schreb., V. tenuifolia subsp. variabilis (Freyn et Sint.) Dinsm., V. villosa subsp. varia (Host) Corb. ( V. dasicarpa auct.), V. villosa subsp. villosa Roth, $V$. loiseleurii (M. Bieb.) H. Lindb. (V. meyeri Boiss.)) toxum nümunələrinin mikromorfologiyası və toxum səthinin quruluşu skan elektron mikroskopu (SEM) vasitəsilə tədqiq edilmişdir. Toxum nümunələri 2015- 2017-ci illərdə Azərbaycanın müxtəlif bölgələrindən (Zaqatala, Ordubad, Xızı, Şamaxı, Masallı, Qəbələ, Lerik, Tovuz) 11 marşrut üzrə toplanılmışdır. Toplanılan toxum nümunələri 2 yarımcins (Vicia, Vicilla) və 8 seksiyaya (Vicia, Hypechusa, Peregrinae, Faba, Narbonensis, Cracca, Lenticula, Ervum) aiddir. Toxum nümunələrində səthin quruluşu, papillaların (toxum səthində əmzik şəkilli çıxıntılar) forması, sıxlığ kəsikli və ya mumlu təbəqəsi skan elektron mikroskopiya metodu (SEM) vasitəsilə öyrənilmişdir. Tədqiqat zamanı toxumun morfoloji əlamətləri, o cümlədən ümumi formas1, ölçüsü, rəngi stereomikroskop vasitəsilə müəyyən edilmişdir. Lərgə taksonlarında toxum səthinin başlıca forması papillalar olmuşdur. Lakin papillalarda yan kəsiklərin ölçüsü və papillaların sıxlığı müxtəlif taksonlarda fərqli olmuşdur. Toxumun dörd morfoloji əlaməti: hilumun nisbi ölçüsü və forması, mikropilenin (toxum girişinin) hiluma nəzərən nisbi yerləşməsi, hilumun toxum səthində tutduğu mövqe sabit olmuşdur. Müəyyən edilmişdir ki, toxum təbəqəsinin mikroskopik tədqiqi mühüm rol oynayır və yarımcins və seksiyaların statusunun dəqiqləşdirilməsində istifadə oluna bilər. Toxumun digər əlamətləri (formas1, rəngi, toxumun ölçüsü) isə taksonların təyin olunmasında qiymətli hesab edilir.

Açar sözlor: Vicia, toxum mikromorfologiyası, SEM, takson, seksiya, növ

\section{Микроморфологическое строение семян некото- рых таксонов вики распространенных в Азер- байджане}

Камаля В. Асадова

Айдын М. Аскеров

Институт Генетических Ресурсов НАНА, 1106, проспект Азадлыг 155, Баку, Азербайджан

Впервые проведено детальное микроморфологическое исследование образцов семян и анализ структуры семенной поверхности 17 видов и подвидов дикой вики (Vicia L.), представленных во флоре Азербайджана ( $V$. bithynica (L.) L., $V$. sativa subsp. cordata Wulf, ex Hoppe, $V$. elegans Guss, $V$. hirsuta (L.) S. F Gray, $V$. hybrida L., V. lutea L., V. monantha Retz ( $V$. cinerea Bieb.), $V$. narbonensis L. ( $V$. johannis Tamamsch.), $V$. pannonica Crantz, $V$. peregrina L., $V$. sativa subsp. nigra (L.) Ehrh. (V. angustifolia Reichard), $V$. sativa subsp. sativa L., V. tetrasperma (L.) Schreb., V. tenuifolia subsp. variabilis (Freyn et Sint.) Dinsm., $V$. villosa subsp. varia (Host) Corb. ( $V$. dasicarpa 
auct.), $V$. villosa subsp. villosa Roth, $V$. loiseleurii (M. Bieb.) H. Lindb. (V. meyeri Boiss.)). Образцы семян были собраны на 11 маршрутах из разных регионов Азербайджана (Закатала, Ордубад, Хызы, Шамахи, Масаллы, Габала, Лерик, Товуз) в 2015-2017 годах. Собранные образцы семян относятся к 2 подродам (Vicia, Vicilla) и 8 секциям (Vicia, Hypechusa, Peregrinae, Faba, Narbonensis, Cracca, Lenticula, Ervum). В образцах структура поверхности, форма, плотность или воскообразный слой сосочков (почки с поверхностью всасывания) были изучены методом сканирующей электронной микроскопии (СЭМ). Морфологические признаки, в том числе общая форма, цвет и размеры семян были изучены под стереомикроскопом во время исследования. Основной формой семенных поверхностей у исследованных таксонов были папиллы. Тем не менее, размер ребер в сосочках (в папиллах) и плотность папилл были разными у разных видов. Четыре морфологических признака семян были стабильными: относительная длина и форма хилума (hilum), относительное расположение микропиле (вход семян) с хилума и положение хилума на поверхности семян. Установлено, что микроскопическое исследование семенной оболочки имеет важное таксономическое значение и эти данные могут быть использованы при уточнении статуса подродов и секций, а остальные признаки семян (форма, цвет, величина семян и т. д.) являются важными при определении внутриродовых и видовых таксонов.

Ключевые слова: Vicia, микроморфология семян, SEM, таксон, секияи, вид 